\title{
Development and Validation of UV Spectrophotometric Method for Simultaneous Estimation of Quinfamide and Mebendazole in in-house Pharmaceutical Formulation
}

\author{
AJINKYA G. DHANDAR, SAURABH B. GANORKAR, AMOD S. PATIL AND \\ ATUL A. SHIRKHEDKAR*
}

Department of Pharmaceutical Chemistry, R. C. Patel Institute of Pharmaceutical Education and Research, Shirpur Distt. Dhule, MH - 425 405, India

*Email: shirkhedkar@gmail.com

Received: December 09, 2017 | Revised: February 11, 2018 | Accepted: February 28, 2018

Published online: May 02, 2018

The Author(s) 2018. This article is published with open access at www.chitkara.edu.in/publications

\begin{abstract}
The present work described the development of two simple, accurate, rapid, cost effective and reproducible UV-Spectrophotometric methods for the simultaneous estimation of Quinfamide and Mebendazole in bulk and in laboratory mixture using $0.01 \mathrm{M}$ methanolic $\mathrm{HCl}$ as a solvent. The absorption maximum for Quinfamide and Mebendazole were found to be at $260.00 \mathrm{~nm}$ and $232.40 \mathrm{~nm}$ respectively. Beer's - lamberts was followed in concentration ranges of $1-6 \mu \mathrm{g} / \mathrm{mL}$ for Quinfamide and 2- $12 \mu \mathrm{g} / \mathrm{mL}$ for Mebendazole. The percentage recovery of Quinfamide and mebendazole ranged from 98.48 to 99.08 and 98.83 to 99.62 (Method I); from 98.14 to 98.93 and 99.16 to 99.35 (Method II) for Quinfamide and Mebendazole. The established methods were sensible for simultaneous quantitative determination of both these drugs in fixed dose combinations. Validation of both these methods was performed as per ICH guidelines. The developed methods can routinely be used for estimation of both these drugs in their combined dosage form.
\end{abstract}

Keyword: Quinfamide; Mebendazole, Vierodt's Method and Multi-component Mode, UV-Spectrophotometer, Validation.

\section{INTRODUCTION}

Journal of Pharmaceutical

Technology, Research and Management

Vol-6, No-1,

May 2018 pp. $9-20$

analysis. The multicomponent formulations provide a greater patient 
Dhandar, AG

Ganorkar, SB

Patil, AS

Shirkhedkar, AA acceptability [1]. Simultaneous equation (Vierodt's Method) is relevant for the estimation of those drugs where the spectra of the drugs overlay accurately and multicomponent analysis can be useful to any extent of spectral overlap provided that two or more spectra are not similar exactly [2]. The fundamental development behind these methods is the measurement of some property which is proportional to amount of analyte in sample. Intestinal parasitic diseases are distributed nearly throughout the world, with huge rates in many regions [3]. Invasive amoebiasis and helminthiasis is a chief health and social difficulty in western and South-eastern Africa, South-east Asia, China, and Latin America, specially in Mexico [4]. The combination of Quinfamide (QFN) and Mebendazole (MEB) is used in the treatment of amebiasis and helminthiasis and both drugs give effective and safe results. QFN is chemically [1-(2, 2-dichloroacetyl)-3, 4-dihydro-2H-quinolin-6-yl] furan-2-carboxylate [5] (Fig. 1) having antiparasitic properties consist of dichloroacetamide function $[6,7]$.QFN is an antiamoebic agent used in the intestinal lumen, is absorbed at least possible levels, and is discard within $48 \mathrm{~h}$, has been recognized to be an efficient clinical antiamoebic in 80 to $90 \%$ of cases linking a single day of treatment $[8,9]$. MEB chemically, Methyl-5-benzoyl-2-benzimidazole carbamate (Fig. 2) is broad spectrum antihelmintic agent [10]. It is BCS class II drug showing low solubility and high permeability [11, 12].

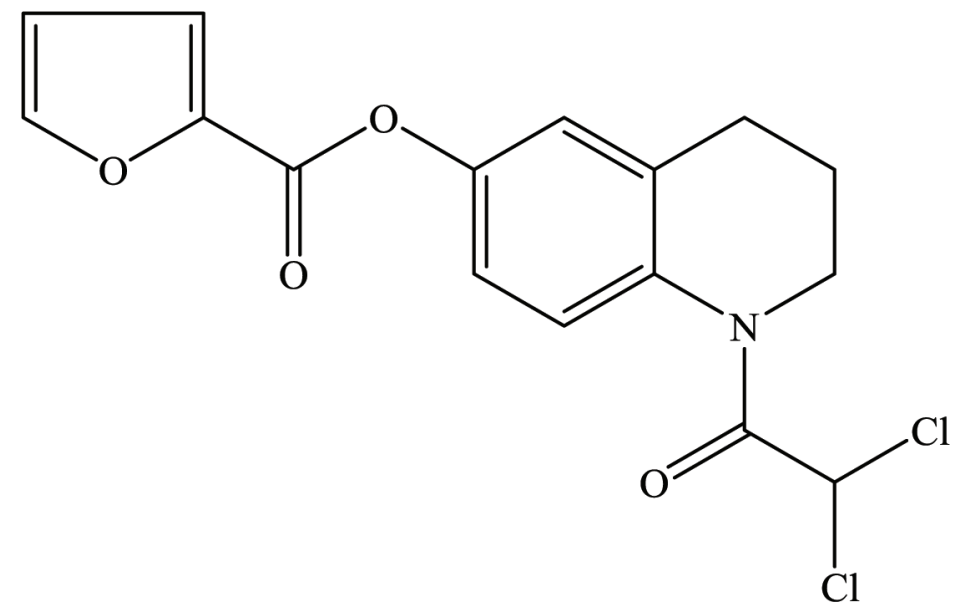

Figure 1: Molecular Structure of Quinfamide.

Literature survey revealed no single established analytical method for the simultaneous determination of Quinfamide and Mebendazole in pharmaceutical 


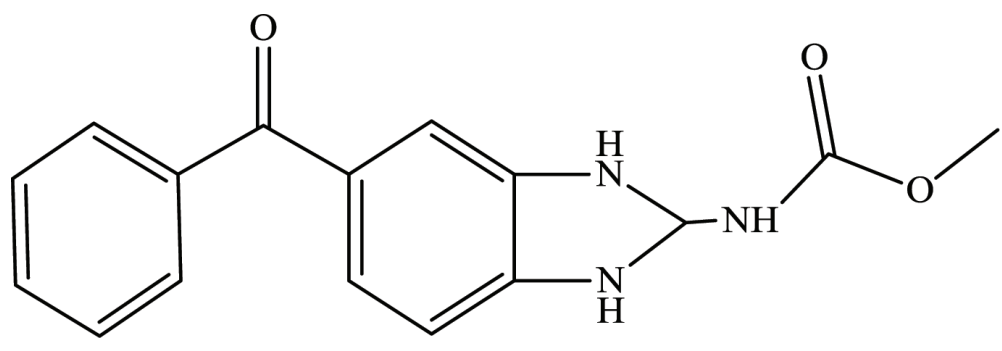

Figure 2: Molecular Structure of Mebendazole.

formulation. Hence, present research work was undertaken with the objective of developing a newer, simple, rapid and cheap simultaneous equation method and multi-component method for the analysis of Quinfamide and Mebendazole in bulk form and laboratory mixture.

\section{MATERIALS AND METHODS}

\subsection{Chemicals}

Quinfamide bulk drug was supplied as a gift sample by RPG Life Science Pvt. Ltd., Mumbai, (MS.) India. Mebendazole bulk drug was supplied as a gift sample by Watson Pharmaceuticals Pvt. Ltd., Mumbai, (MS) India. 0.01 M methanolic $\mathrm{HCl}$ was used throughout the experimental Work.

\subsection{Instrumentation}

A UV-Visible spectrophotometer (2450 Shimadzu and UV-1601, software UV Probe 2.21). The spectral bandwidth $1 \mathrm{~nm}$ was implemented for all spectroscopic measurements, using a pair of $10 \mathrm{~mm}$ matched quartz cells.

\subsection{Preparation of Standard Stock Solution}

Standard Stock solution of QFN and MEB was prepared by dissolving $10 \mathrm{mg}$ in $100 \mathrm{~mL}$ of $0.01 \mathrm{M}$ methanolic $\mathrm{HCl}$ in different flask to obtain the concentration of $100 \mu \mathrm{g} / \mathrm{mL}$ of each drug.

\subsection{Selection of Wavelengths}

From these prepared solution, $1 \mathrm{~mL}$ of QFN and MEB were transferred into two separate $10 \mathrm{~mL}$ volumetric flask and volume was made up to the mark using $0.01 \mathrm{M}$ methanolic $\mathrm{HCl}$ to obtain concentration each of $10 \mu \mathrm{g} / \mathrm{mL}$; the resultant solution was checked in UV-range $(400-200 \mathrm{~nm})$ in $1.0 \mathrm{~cm}$ cell beside solvent blank. The overlain spectrum was determined absorbance of mixture of two drugs (Fig. 3).
Development and

Validation of UV

Spectrophotometric

Method for

Simultaneous

Estimation of

Quinfamide and

Mebendazole

in in-house

Pharmaceutical

Formulation

\section{}


Dhandar, AG

Ganorkar, SB

Patil, AS

Shirkhedkar, AA

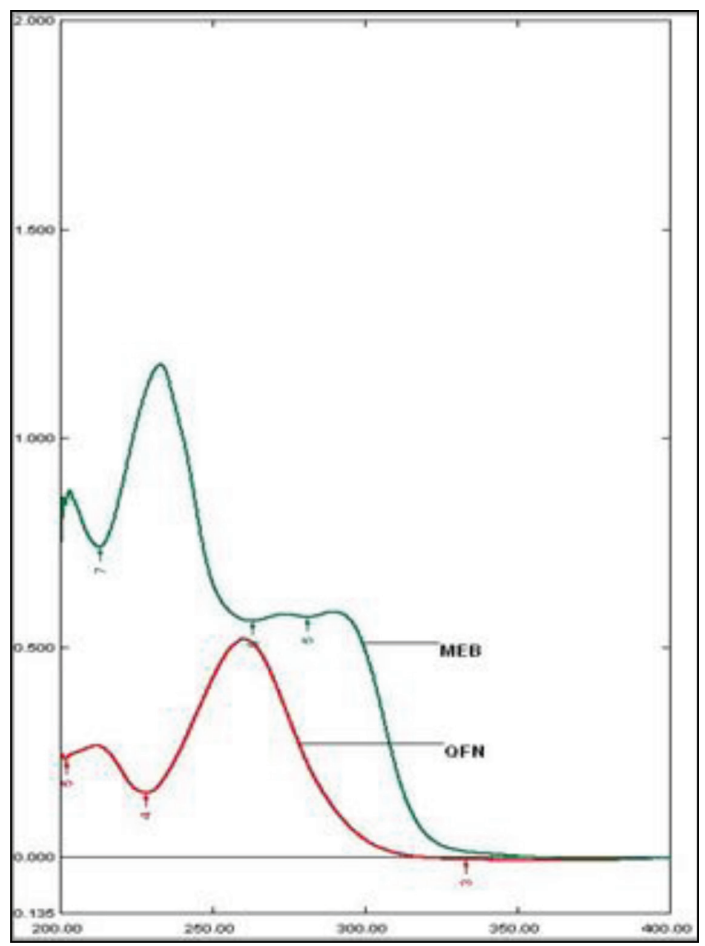

Figure 3: Overlain spectra of Quinfamide and Mebendazole.

\subsection{Preparation of Calibration Curve}

Calibration curve of QFN was prepared using standard stock solution by taking appropriate volumes in the range of $(0.1$ to $0.6 \mathrm{~mL})$ were transferred into series of $10 \mathrm{~mL}$ volumetric flask to obtain concentration of $1,2,3,4,5$, and $6 \mu \mathrm{g} / \mathrm{mL}$. The absorbance of these solutions was recorded initially at $260 \mathrm{~nm}$.

Calibration curve of MEB was prepared using standard stock solution by taking appropriate volumes in the range of $(0.2$ to $1.2 \mathrm{~mL})$ were transferred to series of $10 \mathrm{~mL}$ volumetric and volume were prepared up to the mark using $0.01 \mathrm{M}$ methanolic $\mathrm{HCl}$ to get concentrations in range of 2, 4, 6, 8, 10 and $12 \mu \mathrm{g} / \mathrm{mL}$. The absorbance of this solution was measured at $232.40 \mathrm{~nm}$. The overlain spectrum for mixture $(10 \mu \mathrm{g} / \mathrm{ml}$ each) is shown in (Fig. 4).

\subsection{Method - I (Vierodt's Method)}

Absorbance was measure at the maximum absorption wavelength of two drugs in quantitative determination of two drugs by simultaneous equation. Two wavelengths $260 \mathrm{~nm}$ and $232.40 \mathrm{~nm}$ for QFN and MEB were selected 


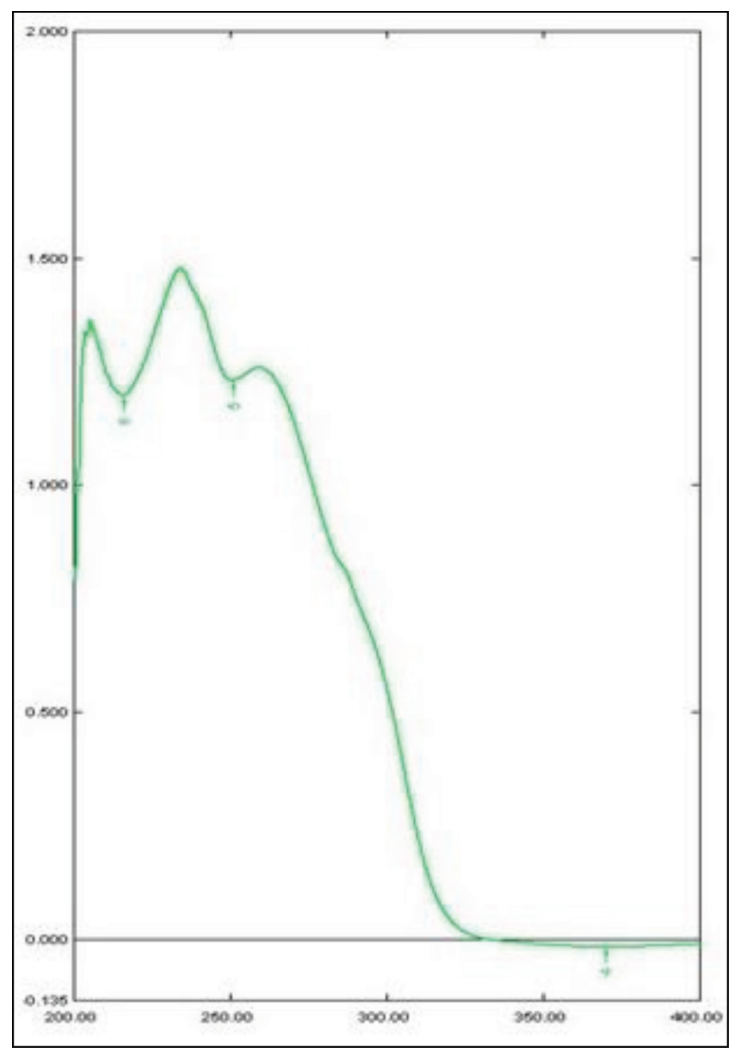

Development and

Validation of UV

Spectrophotometric

Method for

Simultaneous

Estimation of

Quinfamide and

Mebendazole

in in-house

Pharmaceutical

Formulation

Figure 4: Absorbance maxima of Quinfamide and Mebendazole.

and sixed mixed standards solutions QFN and MEB were prepared in $0.01 \mathrm{M}$ methanolic $\mathrm{HCl}$. All prepared standard solution were scanned over the range of $400-200 \mathrm{~nm}$ in simultaneous mode using two sampling wavelength 260 $\mathrm{nm}\left(\lambda_{\max }\right.$ of QFN) and $232.40 \mathrm{~nm}\left(\lambda_{\max }\right.$ of MEB). The absorbance and the $\mathrm{E}$ $(1 \% 1,1 \mathrm{~cm})$ at the particular wavelength were calculated and substituted in the following Vierodt's equation. Demographic parameters like slope, intercept, correlation coefficient, standard deviation, relative standard deviation was calculated.

$$
\begin{aligned}
& \mathrm{Cx}=\mathrm{A} 2 \text { ay1-A1 ay2/ ax2 ay } 1-\mathrm{ax} 1 \mathrm{ay} 2 \\
& \mathrm{Cy}=\mathrm{A} 1 \mathrm{ax} 2-\mathrm{A} 2 \mathrm{ax} 2 / \mathrm{ax} 2 \text { ay } 1-\mathrm{ax} 1 \mathrm{ay} 2
\end{aligned}
$$

Where,

Cx and Cy are the concentrations of $\mathrm{x}(\mathrm{QFN})$ and $\mathrm{y}(\mathrm{MEB})$ 
Dhandar, AG

Ganorkar, SB

Patil, AS

Shirkhedkar, AA

A1 is the absorbance of mixture at $\lambda 1$

A2 is the absorbance of mixture at $\lambda 2$

ax 1 is the $E(1 \%, 1 \mathrm{~cm})$ value of $Q F N$ at $\lambda 1$

ax2 is the $E(1 \%, 1 \mathrm{~cm})$ value of $Q F N$ at $\lambda 2$

ay 1 is the $E(1 \%, 1 \mathrm{~cm})$ value of MEB at $\lambda 1$

ay 2 is the $E(1 \%, 1 \mathrm{~cm})$ value of MEB at $\lambda 2$

A1 is the absorbance of mixture at $260 \mathrm{~nm}, \mathrm{~A} 2$ is the absorbance of mixture at $232.40 \mathrm{~nm}$ and $\mathrm{ax} 1=(864), \mathrm{ax} 2=(340)$, ay $1=(530)$, ay $2=(1104)$ are $\mathrm{E}(1 \%, 1$ $\mathrm{cm})$ of QFN and MEB at $260 \mathrm{~nm}$ and $232.40 \mathrm{~nm}$.

\subsection{Method- II (Multi-component mode of analysis)}

Mixed standard solutions of QFN and MEB were prepared six times in $0.01 \mathrm{M}$ methanolic $\mathrm{HCl}$. In the multicomponent mode, all the standards were scanned over the range of $400-200 \mathrm{~nm}$, using two sampling wavelength $260 \mathrm{~nm}(\lambda$ $\max$ of $\mathrm{QFN}$ ) and $232.40 \mathrm{~nm}(\lambda \max$ of MEB). The scanning data were used to resolve the concentrations of two drugs in solution of laboratory mixture (Fig. 5).

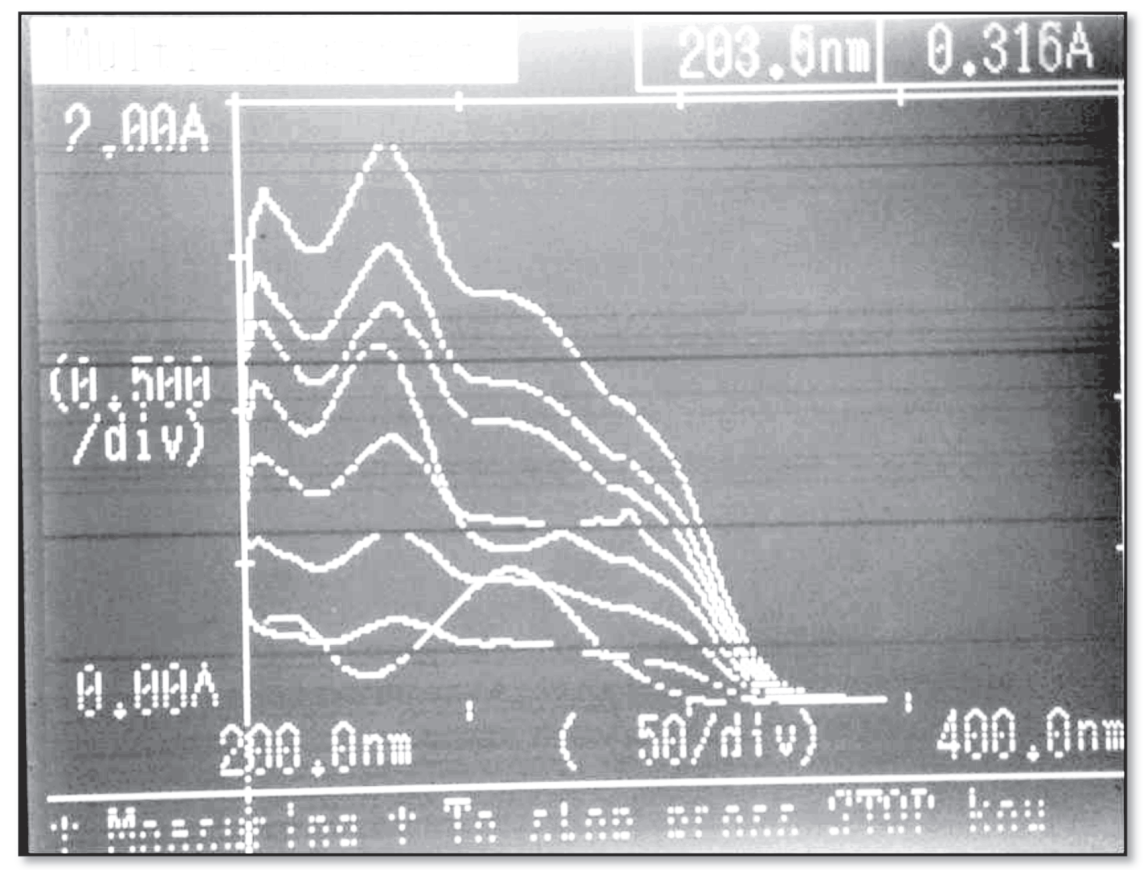

Figure 5: Overlain spectra of Quinfamide (QFN) and Mebendazole (MEB). 


\subsection{Analysis of Laboratory Formulation}

The laboratory formulation was prepared containing $150 \mathrm{mg}$ of QFN and $300 \mathrm{mg}$ of MEB along with commonly used excipient, a quantity of powder drug equivalent $10 \mathrm{mg}$ of QFN and $20 \mathrm{mg}$ of MEB was transferred into $100 \mathrm{~mL}$ volumetric flask containing $60 \mathrm{~mL} 0.01 \mathrm{M}$ methanolic $\mathrm{HCl}$, sonicated for $20 \mathrm{~min}$ and the aggregate was load up to marking and filtered through Whatmann filter paper (no.41). Further, the solution was diluted with $0.01 \mathrm{M}$ methanolic $\mathrm{HCl}$ to obtain the final concentration $4 \mu \mathrm{g} / \mathrm{mL}$ for QFN and $8 \mu \mathrm{g} / \mathrm{mL}$ for MEB. Absorbance of this solution was measured at $260 \mathrm{~nm}$ and $232.40 \mathrm{~nm}$. The quantitative estimation of both these drugs were performed solving simultaneous equation (1) \& equation (2) (Method I). The equivalent quantities of solutions were regulated to investigate in the multicomponent mode present in the instrument (UV-Spectrophotometer 1601). The solution was studied over the wavelength the range of $400-$ $200 \mathrm{~nm}$; the concentration of drugs were stored by analysis of spectral information of the sample solution with reference to the mixed standards (Method II). The analysis procedure was repeated six times with laboratory formulations (Table 1).

Table 1: Results of in-house tablets for Method I and II.

\begin{tabular}{ccccc}
\hline Method & $\begin{array}{c}\text { Amount Taken } \\
(\mu \mathbf{g} / \mathbf{m L})\end{array}$ & $\begin{array}{c}\text { Amount Found } \\
(\mu \mathbf{g} / \mathbf{m L})\end{array}$ & $\begin{array}{c}\% \\
\text { Amount Found }\end{array}$ & $\begin{array}{c}\text { \% } \\
\text { RSD }\end{array}$ \\
\hline I & $\begin{array}{c}4(\mathrm{QFN}) \\
8(\mathrm{MEB})\end{array}$ & 3.89 & 98.29 & 0.71 \\
& & 7.91 & 98.93 & 1.03 \\
& & & & \\
II & $4(\mathrm{QFN})$ & 3.91 & 98.95 & 1.07 \\
& $8(\mathrm{MEB})$ & 7.94 & 99.29 & 0.64 \\
\hline
\end{tabular}

$\mathrm{N}=$ Number of determinations $(\mathrm{N}=6)$

\subsection{Method Validation Parameters}

The method was developed and validated according as per ICH guideline [13]. All parameter such as accuracy, precision, linearity, DL and QL and for the analytes were found to be within the limit and satisfactory.

\subsection{Accuracy}

The accuracy of the suggested method was confirmed by recovery investigation with the addition of known amounts to tablet, at three contrasting percentage
Development and

Validation of UV

Spectrophotometric

Method for

Simultaneous

Estimation of

Quinfamide and

Mebendazole

in in-house

Pharmaceutical

Formulation . 
Dhandar, AG

Ganorkar, SB

Patil, AS

Shirkhedkar, AA

levels $(80 \%, 100 \%$, and $120 \%)$ in a period of the area of linearity for both the drugs (Table 2 and 3 ).

Table 2: Results of accuracy study (Method I).

\begin{tabular}{llllll}
\hline $\begin{array}{l}\text { Initial Amount } \\
(\mu \mathbf{g} / \mathbf{m L})\end{array}$ & $\begin{array}{l}\text { Amount } \\
\text { Added } \\
(\mu \mathbf{g} / \mathbf{m L})\end{array}$ & $\begin{array}{l}\text { Total } \\
\text { Amount }\end{array}$ & $\begin{array}{l}\text { Amount } \\
\text { Recovered } \\
(\mu \mathbf{g} / \mathbf{m L})\end{array}$ & $\begin{array}{l}\text { \% } \\
\text { Recovery }\end{array}$ & $\begin{array}{l}\% \\
\text { RSD }\end{array}$ \\
\hline $\mathbf{Q F N}$ & 1.6 & 3.6 & 3.52 & 98.77 & 0.80 \\
$\mathbf{2}$ & 2 & 4 & 3.96 & 99.08 & 0.31 \\
& 2.4 & 4.4 & 4.33 & 98.48 & 1.08 \\
$\mathbf{M E B}$ & 3.2 & 7.2 & 7.17 & 99.62 & 0.17 \\
$\mathbf{4}$ & 4 & 8 & 7.97 & 99.62 & 0.30 \\
& 4.8 & 8.8 & 8.43 & 98.83 & 1.47 \\
\hline
\end{tabular}

$\mathbf{N}=$ Number of determinations $(\mathbf{N}=3)$

Table 3: Results of accuracy study (Method II).

\begin{tabular}{cccccc}
\hline $\begin{array}{c}\text { Initial } \\
\text { Amount } \\
(\mu \mathbf{g} / \mathbf{m L})\end{array}$ & $\begin{array}{c}\text { Amount } \\
\text { Added } \\
(\mu \mathbf{g} / \mathbf{m L})\end{array}$ & $\begin{array}{c}\text { Total } \\
\text { Amount }\end{array}$ & $\begin{array}{c}\text { Amount } \\
\text { Recovered } \\
(\mu \mathbf{g} / \mathbf{m L})\end{array}$ & $\begin{array}{c}\% \\
\text { Recovery }\end{array}$ & $\begin{array}{c}\% \\
\text { RSD }\end{array}$ \\
\hline $\mathbf{Q F N}$ & 1.6 & 3.6 & 3.53 & 98.14 & 0.96 \\
$\mathbf{2}$ & 2 & 4 & 3.92 & 98.16 & 0.66 \\
& 2.4 & 4.4 & 4.35 & 98.93 & 0.47 \\
$\mathbf{M E B}$ & 3.2 & 7.2 & 7.15 & 99.35 & 0.34 \\
$\mathbf{4}$ & 4 & 8 & 7.94 & 99.33 & 0.42 \\
& 4.8 & 8.8 & 8.72 & 99.16 & 0.37 \\
\hline
\end{tabular}

$\mathrm{N}=$ Number of determinations $(\mathrm{N}=3)$

\subsection{Precision}

Assay method precision (intra-day precision) was established by carrying out four assay of test samples by the same analyst with the same equipment; whereas inter-day precision effect evaluation of modification in analysis when the method is used on different days. The \% RSD values of the response was found to be less than $2 \%$ (Table 4 and 5) for intra-day and inter-day precision, respectively.

Repeatability of the scanning device and injection was studied by applying and analyzing samples six times. The \% RSD values were less than 2.0 (Table 6 and 7), representing that the method is repeatable and irreducible. 
Table 4: Results of precision studies (Method I).

\begin{tabular}{cccccc}
\hline Drugs & $\begin{array}{c}\text { Concentration } \\
(\mu \mathbf{g} / \mathbf{m L})\end{array}$ & \multicolumn{2}{c}{ Intra day } & \multicolumn{2}{c}{ Inter day } \\
& & Amount found $(\mu \mathbf{g} / \mathbf{m L})$ & \multicolumn{2}{c}{ Amount found $(\mu \mathrm{g} / \mathbf{m L})$} \\
& & Mean \pm SD & \% & Mean \pm SD & \% \\
& & RSD & & RSD \\
\hline \multirow{2}{*}{ QFN } & 3 & $2.98 \pm 0.005$ & 0.17 & $2.98 \pm 0.007$ & 0.81 \\
& 4 & $3.91 \pm 0.030$ & 0.38 & $3.91 \pm 0.024$ & 0.40 \\
\cline { 2 - 6 } MEB & 4 & $3.95 \pm 0.018$ & 0.21 & $3.95 \pm 0.018$ & 0.56 \\
& 6 & $5.96 \pm 0.007$ & 0.11 & $5.95 \pm 0.012$ & 0.75 \\
& 8 & $7.91 \pm 0.299$ & 0.25 & $7.90 \pm 0.076$ & 1.47 \\
\hline
\end{tabular}

$\mathrm{N}=$ Number of determinations $(\mathrm{N}=3)$

Table 5: Results of precision studies (Method II).

\begin{tabular}{cccccc}
\hline Drugs & $\begin{array}{c}\text { Conc. } \\
(\mu \mathbf{g} / \mathbf{m L})\end{array}$ & \multicolumn{2}{c}{$\begin{array}{c}\text { Intra day } \\
\text { Amount found }(\mu \mathbf{g} / \mathbf{m L})\end{array}$} & \multicolumn{2}{c}{ Inter day } \\
& & $\begin{array}{c}\text { Mean } \pm \text { SD } \\
{[\mathbf{n}=\mathbf{3}]}\end{array}$ & $\begin{array}{c}\text { \% } \\
\text { RSD }\end{array}$ & $\begin{array}{c}\text { Mean } \pm \text { SD } \\
{[\mathbf{n}=\mathbf{3}]}\end{array}$ & \% \\
& & $1.93 \pm 0.011$ & 0.59 & $1.94 \pm 0.020$ & 1.06 \\
\hline \multirow{2}{*}{ QFN } & 2 & $2.98 \pm 0.020$ & 0.70 & $2.95 \pm 0.049$ & 1.66 \\
& 3 & $3.90 \pm 0.049$ & 1.26 & $3.92 \pm 0.037$ & 0.96 \\
\hline \multirow{2}{*}{ MEB } & 4 & $3.95 \pm 0.017$ & 0.438 & $3.95 \pm 0.032$ & 0.81 \\
& 6 & $5.91 \pm 0.020$ & 0.35 & $5.94 \pm 0.020$ & 0.35 \\
& 8 & $7.93 \pm 0.060$ & 0.767 & $7.89 \pm 0.105$ & 1.33 \\
\hline
\end{tabular}

$\mathrm{N}=$ Number of determinations $(\mathrm{N}=3)$

Table 6: Results of repeatability study.

Method I Method II

\begin{tabular}{ccccc}
\hline Drugs & $\begin{array}{c}\text { \% } \\
\text { Amount found } \\
\pm \text { SD }\end{array}$ & $\begin{array}{c}\% \\
\text { RSD }\end{array}$ & $\begin{array}{c}\text { \% } \\
\text { Amount found } \pm \\
\text { SD }\end{array}$ & $\begin{array}{c}\text { \% } \\
\text { RSD }\end{array}$ \\
\hline QFN & $98.08 \pm 1.10$ & 1.12 & $97.79 \pm 1.17$ & 1.20 \\
MEB & $99.08 \pm 0.52$ & 0.52 & $99.10 \pm 0.49$ & 0.50 \\
\hline Number of determinations $(\mathrm{N}=6)$ & & & \\
\hline
\end{tabular}


Dhandar, AG

Ganorkar, SB

Patil, AS

Shirkhedkar, AA

Table 7: Validation Parameters for Quinfamide and Mebendazole.

\begin{tabular}{|c|c|c|c|c|}
\hline \multirow[t]{2}{*}{ Parameters } & \multicolumn{2}{|c|}{ QFN } & \multicolumn{2}{|c|}{ MEB } \\
\hline & Method I & Method II & Method I & Method II \\
\hline $\begin{array}{c}\text { Working } \\
\text { Wavelengths(nm) }\end{array}$ & 260 & 260 & 232.40 & 232.40 \\
\hline $\begin{array}{l}\text { Linearity Range } \\
\qquad(\mu \mathrm{g} / \mathrm{mL})\end{array}$ & $1-6$ & $1-6$ & $2-12$ & $2-12$ \\
\hline \multicolumn{5}{|c|}{ Precision(\% RSD) } \\
\hline Inter-day $(n=3)$ & $0.40-1.03$ & $0.96-1.66$ & $0.56-1.47$ & $0.35-1.33$ \\
\hline Intra-day $(\mathrm{n}=3)$ & $0.17-0.38$ & $0.59-1.26$ & $0.11-0.25$ & $0.35-0.76$ \\
\hline $\begin{array}{l}\text { Repeatability } \\
\quad(\mathrm{n}=6)\end{array}$ & 1.12 & 1.20 & 0.52 & 0.50 \\
\hline \multicolumn{5}{|c|}{$\begin{array}{c}\text { Ruggedness } \\
\text { [\% RSD] }\end{array}$} \\
\hline Analyst I $(n=6)$ & 0.89 & 0.88 & 1.36 & 0.23 \\
\hline Analyst II ( $n=6)$ & 0.85 & 0.55 & 0.53 & 0.91 \\
\hline \multicolumn{5}{|c|}{$\begin{array}{c}\% \text { Recovery } \\
(n=3)\end{array}$} \\
\hline \% RSD & $\begin{array}{c}98.77-99.48 \\
0.73\end{array}$ & $\begin{array}{c}98.14-98.93 \\
0.30\end{array}$ & $\begin{array}{c}98.83-99.62 \\
0.73\end{array}$ & $\begin{array}{c}99.16-99.35 \\
1.03\end{array}$ \\
\hline
\end{tabular}

\subsection{Sensitivity}

Sensitivity of the method was predicted as Detection Limit (DL) and Quantification Limit (QL). The DL and QL were estimated by the use of the comparison $\mathrm{DL}=3.3 \mathrm{XASD} / \mathrm{S}$ and $\mathrm{QL}=10 \mathrm{XASD} / \mathrm{S}$; where, 'ASD' is Average standard deviation of the peak height and areas of the drug $(n=3)$, taken as a measure of noise, and ' $\mathrm{S}$ ' is the slope of the corresponding calibration plot. The procedure was repeated in triplicate. In method I LOD and LOQ for QFN was 0.26 and $\mathbf{0 . 8 0} \mu \mathbf{g}$ as well as for MEB 0.26 and $0.79 \mu \mathrm{g}$ and in method II for QFN was 0.30 and $0.91 \mu \mathrm{g}$ as well as for MEB 0.25 and $0.77 \mu \mathrm{g}$, respectively.

\section{RESULTS AND DISCUSSION}

Quinfamide and Mebendazole depicted good linearity over the concentration range of $1-6 \mu \mathrm{g} / \mathrm{ml}$ and $2-12 \mu \mathrm{g} / \mathrm{ml}$ using $0.01 \mathrm{M}$ methanolic $\mathrm{HCl}$ for these 
two methods at their particular $\lambda$ max with coefficient correlation. Laboratory formulations were analyzed. The amounts of QFN and MEB determined by 'Method I' was found to be 98.29 and 98.93, respectively; while, by 'Method II', it was found to be 98.95 and 99.29 , respectively. The proposed method was validated as per ICH guideline. The percentage recovery was decisive by designing by mean percentage recovery. It was studied at 80,100 and $120 \%$. Precision was determined as repeatability (\% RSD is less than 2.0) and interday- intra-day deviation (\% RSD is less than 2.0) for both drugs. The ruggedness of the process was examined by two particular analysts keeping same operative and environmental conditions. Sensitivity of the method was examined as limit of detection and limit of quantification. The analyzed data like, \% recovery, repeatability data, ruggedness data are presented in details (Table 7).

\section{CONCLUSION}

The developed methods were found to be simple, rapid, reproducible and precise and can be used for quality control analysis of Quinfamide and Mebendazole in bulk and may be conveniently extended towards determination of drug in pharmaceutical formulations.

\section{ACKNOWLEDGMENT}

The authors are thankful to R.C. Patel Institute of Pharmaceutical Education and Research, Shirpur Dist: Dhule (MS) 425405.

\section{REFERENCES}

[1] Gouda, A.A., El-Sayed, M.I., Amin, A.S. and El Sheikh, R., 2013. Spectrophotometric and spectroflurometric methods for the determination of non-steroidal anti-inflammatory drugs: A review. Arabian Journal of Chemistry, 6 (2), 145-63. https://doi.org/10.1016/j.arabjc.2010.12.006

[2] Rojas, F. S., Ojeda and C. B., 2009. Recent development in derivative ultraviolet/ visible absorption spectrophotometry, a review. Analytica Chimica Acta, 635 (1), 22-44.

[3] WHO Expert Committee, 1987. Public health significance of intestinal parasitic infections. Bulletin of the World Health Organization, 65 (5), 575.

[4] Assob, J. C., Nsagha, D.S., Njouendou, A. J., Zofou, D., Sevidzem, W. F., Ketchaji, A., Chiara, A., Asangbeng, T. E., Dzemo, K. O., Samba, B. M. and Wenze, A. C., 2017. Diseases in Africa: An Overview. In Medicinal Spices and Vegetables from Africa, 1-69.

[5] Morales, J. M., Jung, C. H., Alarcón, A. and Barreda, A., 2000. Solid-phase extraction and liquid chromatographic quantitation of quinfamide in biological samples. Journal of Chromatography. Biomedical Sciences and Application, 746 (2), 133-9.
Development and

Validation of UV

Spectrophotometric

Method for

Simultaneous

Estimation of

Quinfamide and

Mebendazole

in in-house

Pharmaceutical

Formulation

Formulation


Dhandar, AG

Ganorkar, SB

Patil, AS

Shirkhedkar, AA
[6] Aquino, I., Alcalá, Y., Gutiérrez, L., Tapia, G., Jung, H. and Sumano, H. 2016. In vivo anticoccidial activity of quinfamide in broilers: a preliminary report. Italian Journal of Animal Science, 15 (4), 689-95. https://doi.org/10.1080/1828051X.2016.1229585

[7] Nagarajan K., 2006. Creative research in the chemical industry-Four decades in retrospect. Journal of Chemical Sciences, 118 (4), 291-309. https://doi.org/10.1007/BF02708523

[8] Davila-Gutierrez, C. E., Vasquez, C., Trujillo-Hernandez, B. and Huerta, M., 2002. Nitazoxanide compared with quinfamide and mebendazole in the treatment of helminthic infections and intestinal protozoa in children. The American journal of tropical medicine and hygiene, 66 (3), 251-4. https://doi.org/10.4269/ajtmh.2002.66.251

[9] Padilla, N., Diaz, R., Alarcon, A. and Barreda, R., 2002. Antiamoebic chemoprophylaxis using quinfamide in children: a comparative study. The Scientific World Journal, (2), 1070. https://doi.org/10.1100/tsw.2002.174

[10] Liu, H., Jiang, C., Hui, Y., Shen, X., Zhang, X. and Yu, H. 2010. SPE-LC multiresidue analysis of mebendazole and its metabolites in grass carp and shrimp. Chromatographia, 72(11-12), 1083-8. https://doi.org/10.1365/s10337-010-1768-6

[11] Parakh, D. R., Madagul, J. K., Mene, H. R., Patil, M. P. and Kshirsagar, S. J. 2016. RP-HPLC method development and validation for Quantification of Mebendazole in API and Pharmaceutical Formulations. PharmaTutor, 4(5), 46-51.

[12] Eskandari, M., Yamini, Y., Fotouhi, L. and Seidi, S. 2011. Microextraction of mebendazole across supported liquid membrane forced by $\mathrm{pH}$ gradient and electrical field. Journal of pharmaceutical and biomedical analysis, 54(5), 1173-9. https://doi.org/10.1016/j.jpba.2010.12.006

[13] ICH guidelines: Q2(1) Validation of Analytical Procedure : Text and Methodology 1996.

\section{Abbreviations}

- QFN-Quinfamide

- MEB-Mebendazole

- UV- Ultra Violet

- VIS- Visible

- $\mathrm{Mg} / \mathrm{mL}-$ Micro Gram/ Milliliter

- mL-Milliliter

- DL-Detection of Limit

- QL-Quantification of Limit

- ASD-Average Standard Deviation

- $\quad \%$ RSD-Percentage Relative Standard Deviation

- SD-Standard Deviation

- ICH-International Council on Harmonization 